\title{
Perencanaan Produksi Minyak Biji Kapuk di PT. Singa Mas Anuge rah Berkah
}

\section{Cotton Seed Oil Production Planning at PT. Singa Mas Anugerah Berkah}

\author{
Christian Adi Wibowo, Teguh Oktiarso \\ Universitas Ma Chung, Malang \\ E-mail: c.adi.wibowo19@gmail.com, teguh.oktiarso@machung.ac.id
}

\begin{abstract}
Abstrak
PT. Singa Mas Anugerah Berkah adalah perusahaan manufaktur yang memproduksi minyak nabati berbahan dasar biji kapuk. Perencanaan produksi di perusahaan ini dinilai kurang karena proses produksi dan sumber daya yang ada belum terintegrasi dengan baik. Perencanaan produksi merupakan kegiatan untuk menentukan jumlah produk yang harus diproduksi untuk memenuhi permintaan pasar. Perencanaan produksi agregat dilakukan untuk mengetahui berapa banyak produk yang harus diproduksi dengan mempertimbangkan sumber daya yang ada. Peramalan permintaan dilakukan untuk mengetahui perkiraan permintaan pada periode yang akan datang. Metode yang terpilih adalah regresi linear karena permintaan cenderung menurun setiap tahunnya. Hasil dari penelitian ini adalah jadwal induk produksi untuk memenuhi kebutuhan pasar.

Kata kunci: perencanaan produksi, perencanaan agregat, jadwal induk produksi
\end{abstract}

PT. Singa Mas Anugerah Berkah is a manufacturing company that produced vegetable oil made from cotton seed. Production planning at this company rated poorly because the production process yet integrated with the existing resources. Production planning is an activity to determine the quantity of product needed to be produced for market demand. Aggregate planning conducted to determine how many product to be produced while considering available resources. Demand forecasting carried to determine estimated demand for next period. The chosen method is linear regression because the estimated demand tend to decrease every year. The final result is a master production schedule to fulfil the market demand.

Keywords: production planning, aggregate planning, master production schedule

\section{Pendahuluan}

PT. Singa Mas Anugerah Berkah merupakan perusahaan yang bergerak di bidang manufaktur pembuatan minyak nabati dengan bahan dasar biji kapuk. Produk yang dihasilkan adalah minyak nabati dan bungkil ampas biji kapuk atau yang biasa disebut klentheng. PT. Singa Mas Anugerah Berkah belum mengintegrasikan proses produksinya dengan faktor pendukung lain suplai bahan baku, permintaan, dan tenaga kerja. Selama ini mereka melakukan proses produksi mengikuti bahan baku yang tersedia. Selama bahan baku tersedia mereka memaksimalkan produksi mereka tanpa mempertimbangkan faktor-faktor lain yang mempengaruhi proses produksi. Oleh karena itu mereka sering mengalami kelebihan produksi saat permintaan turun dan terkadang mengalami kekurangan stok saat permintaan ekspor datang dalam jumlah yang besar. Penjadwalan yang kurang baik dapat memberikan dampak buruk untuk perusahaan. Overstock dapat menimbulkan biaya simpan yang seharusnya dapat dihindari. Biaya simpan sendiri merupakan opportunity cost yang dapat digunakan untuk hal lain selain menyimpan finish good. Selain overstock, perusahaan beresiko mengalami lost sales ketika ada permintaan dalam jumlah besar namun tidak dapat memenuhi permintaan tersebut. Berdasarkan permasalahan tersebut, dilakukan penelitian untuk dapat membuat jadwal produksi untuk PT. Singa Mas Anugerah Berkah.

\section{Tinjauan Pustaka}

Tinjauan pustaka merupakan bekal awal untuk melakukan sebuah penelitian. Dari tinjauan pustaka didapatkan metode-metode yang akan digunakan untuk melakukan perbaikan. Berikut ini adalah tinjauan pustaka yang digunakan pada penelitian ini. 


\subsection{Forecasting}

Peramalan perlu dilakukan untuk mengetahui perkiraan permintaan yang akan datang. Metode peramalan yang sering digunakan adalah metode kuantitatif. Salah satu metode kuantitatif adalah metode time series. Metode time series memiliki beberapa model yaitu (Herjanto, 2007):

1. Moving Average

Metode ini menggunakan data aktual permintaan untuk menghasilkan nilai ramalan permintaan di masa mendatang dan memiliki model sebagai berikut:

$$
F t=\left(A_{t-1}+A_{t-2}+A_{t-3}+\ldots+A_{t-p}\right) / p
$$

Dimana:

$\mathrm{F}_{\mathrm{t}}=$ Peramalan periode $\mathrm{t}$

$\mathrm{A}_{\mathrm{t}-1}=$ Demand actual pada periode $\mathrm{t}-1$

$\mathrm{p} \quad=$ Jumlah periode

2. Exponential Smoothing

Metode ini merupakan metode yang seing dipakai untuk peramalan jangka pendek karena mudah dipahami dan diimplementasikan. Model dari metode ini adalah:

$F t=\alpha \cdot A_{t-1}+(1-\alpha) \cdot F_{t-1}$

Dimana:

$\mathrm{Ft}=$ Peramalan periode $\mathrm{t}$

$\mathrm{A}_{\mathrm{t}-1}=$ Demand aktual periode $\mathrm{t}-1$

$\mathrm{F}_{\mathrm{t}-1}=$ Peramalan pada $\mathrm{t}-1$

3. Regresi Linear

Metode ini memilik model seperti berikut:

$F_{t}=m t+b$

Dimana:

$\mathrm{F}_{\mathrm{t}}=$ Peramalan periode $\mathrm{t}$

$\mathrm{b}=$ Intercept

$\mathrm{m}=$ Slope

$\mathrm{t} \quad=$ Periode waktu

Sedangkan untuk mencari nilai $\mathrm{m}$ dan $\mathrm{b}$ menggunakan rumus sebagai berikut:

$m=\frac{\Sigma\left(t-t^{J}\right)(A-\hat{A})}{\Sigma\left(t-t^{J}\right)^{2}}$

$b=\hat{A}-m t^{\prime}$

Dimana:

$\mathrm{A}=$ Demand actual

$\widehat{A}=$ Rata-rata demand actual keseluruhan

$\mathrm{t} \quad=$ Periode waktu

t' = Rata-rata periode waktu keseluruhan

Dalam melakukan peramalan pasti ada kemungkinan terjadinya kesalahan (forecast error). Oleh karena itu perlu dilakukan perhitungan mean absolute deviation (MAD) untuk mengukur kesalahan peramalan dengan rumus:

$M A D=\sum_{t=1}^{n} \frac{\left|x_{t}-x_{t-1}\right|}{n}$

Setelah menghitung MAD, dilanjutkan dengan melakukan aggregate planning.

\subsection{Aggregate Planning}

Aggregate Planning merupakan salah satu metode yang biasa digunakan untuk membuat perencanaan produksi. Aggregate planning sendiri berarti menggabungkan seluruh sumber daya yang sesuai ke dalam istilah yang lebih umum dan menyeluruh (Sukendar dan Kristomi, 2008). Metode aggregate planning yang akan digunakan di penelitian ini ada lah metode optimasi dengan program linear. 


\section{JOURNAL OF INTEGRATED S YSTEM VOL 1. NO. 2, DES EMB ER 2018: 128-138}

Model program linear bukan merupakan suatu model yang mutlak. Oleh karena itu, dapat disesuaikan sesuai kebutuhan dan keadaan yang ada di perusahaan. Berikut merupakan contoh model program linear (Sukendar dan Kristomi, 2008):

$\operatorname{Min} Z=\sum_{t=1}^{T} A_{p, t}+A_{r, t} R_{t}+A_{0} O_{t}+A_{i, t} I_{t}+S_{t}+A_{k_{t} t} H_{t}+A_{l_{t}} L_{t}$

Terhadap:

$\mathrm{I}_{\mathrm{t}}-\mathrm{S}_{\mathrm{t}}=\mathrm{I}_{\mathrm{t}-1}-\mathrm{S}_{\mathrm{t}-1}+\mathrm{P}_{\mathrm{t}}-\mathrm{F}_{\mathrm{t}} \quad$ for $\mathrm{t}=1,2, \ldots, \mathrm{T}$

$\mathrm{R}_{\mathrm{t}}=\mathrm{R}_{\mathrm{t}-1}+\mathrm{H}_{\mathrm{t}}-\mathrm{L}_{\mathrm{t}} \quad$ for $\mathrm{t}=1,2, \ldots, \mathrm{T}$

$\mathrm{O}_{\mathrm{t}}-\mathrm{U}_{\mathrm{t}}=\mathrm{kP}_{\mathrm{t}}-\mathrm{R}_{\mathrm{t}} \quad$ for $\mathrm{t}=1,2, \ldots, \mathrm{T}$

$\mathrm{P}_{\mathrm{t}}, \mathrm{R}_{\mathrm{t}}, \mathrm{O}_{\mathrm{t}}, \mathrm{I}_{\mathrm{t}}, \mathrm{S}_{\mathrm{t}}, \mathrm{H}_{\mathrm{t}}, \mathrm{L}_{\mathrm{t}}, \mathrm{U}_{\mathrm{t}} \geq 0 \quad$ for $\mathrm{t}=1,2, \ldots, \mathrm{T}$

Keterangan:

$\mathrm{P}_{\mathrm{t}} \quad=$ produksi yang dija dwalkan untuk periode $\mathrm{t}$

$\mathrm{A}_{\mathrm{p}, \mathrm{t}} \quad=$ biaya per unit produksi (kecuali biaya tenaga kerja)

$\mathrm{R}_{\mathrm{t}} \quad=$ jam kerja yang ada untuk waktu regular pada periode $\mathrm{t}$

$\mathrm{A}_{\mathrm{r}, \mathrm{t}} \quad$ = biaya tenaga kerja per jam untuk waktu regular

$\mathrm{A}_{\mathrm{o}, \mathrm{t}} \quad$ = biaya tenaga kerja per jam untuk lembur

$\mathrm{I}_{\mathrm{t}} \quad=$ persediaan pada akhir periode $\mathrm{t}$

$\mathrm{A}_{\mathrm{i}, \mathrm{t}} \quad=$ biaya simpan per unit persediaan

$\mathrm{S}_{\mathrm{t}} \quad=$ kuantitas stockout pada akhir periode $\mathrm{t}$

$\mathrm{A}_{\mathrm{s}, \mathrm{t}} \quad=$ biaya per unit stockout

$\mathrm{H}_{\mathrm{t}} \quad$ = jumlah tambahan tenaga kerja baru dalam satuan jam kerja untuk periode $\mathrm{t}$

$\mathrm{A}_{\mathrm{h}, \mathrm{t}} \quad$ = biaya yang dike luarkan untuk menambah tenaga kerja untuk satu jam

$\mathrm{L}_{\mathrm{t}} \quad=$ jumlah pengurangan tenaga kerja dalam satuan jam kerja untuk periode $\mathrm{t}$

$\mathrm{A}_{1, \mathrm{t}} \quad=$ biaya yang dike luarkan untuk mengurangi tenaga kerja untuk satu jam

$\mathrm{U}_{\mathrm{t}} \quad=$ jam kerja sisa pada periode $\mathrm{t}$ jika tingkat produksi kurang dari kapasitas produksi maksimal

$\mathrm{F}_{\mathrm{t}} \quad=$ peramalan permintaan pada periode $\mathrm{t}$

$\mathrm{k} \quad=$ faktor konversi da lam jam kerja per unit barang

$\mathrm{T} \quad=$ jumlah periode yang direncanakan

Langkah yang dilakukan setelah aggregate planning ada melakukan disagregasi rencana agregat.

\subsection{Dis agregasi Perencanaan Agregat}

Disagregasi rencana agregat dilakukan untuk mendapatkan kuantitas produksi untuk masingmasing produk. Metode yang digunakan adalah Bitran dan Hax (Bitran dkk, 1982). Tahapan disagregasi rencana agregat adalah sebagai berikut:

1. Family Disaggregation (Disagregasi Famili)

Metode yang dikenalkan oleh Bitran dan Hax adalah sebuah model knapsack yang kemudian dimodifikasi oleh Bedworth dan Bailey sebagai berikut:

$\operatorname{Min} Z=\sum_{\forall i \in Z}\left(\frac{h_{i} x_{i}}{2}+\frac{s_{i}}{x_{i}} \sum_{j \in i} K_{i j} D_{i j, t}\right)$

Terhadap:

$\sum_{i \in Z} x_{i}=x_{*}$

$x_{i} \geq L B$

$x_{i} \leq U B$

Keterangan:

$\mathrm{S}_{\mathrm{i}} \quad$ = biaya setup untuk memproduksifamily $\mathrm{i}$

$\mathrm{X}_{*} \quad=$ kebutuhan produksi rencana agregat

$\mathrm{K}_{\mathrm{ij}} \quad=$ faktor konversi untuk tiap unit item $\mathrm{j}$ da lam family $\mathrm{i}$ terhadap unit produksi agregat

$\mathrm{D}_{\mathrm{ij}, \mathrm{t}} \quad=$ permintaan untuk item $\mathrm{j}$ pada family $\mathrm{i}$ selama periode $\mathrm{t}$

$\mathrm{h}_{\mathrm{i}} \quad$ = biaya simpan untuk item pada family $\mathrm{i}$

$\mathrm{x}_{\mathrm{i}} \quad=$ jumlah unit yang diproduksi untuk family $\mathrm{i}$ 
PERENCANAAN PRODUKS I MINYAK B IJ I KAPUK (Christian A.W., dkk.)

$\mathrm{LB}_{\mathrm{i}} \quad=$ batas bawah produksi untuk family $\mathrm{i}$

$\mathrm{UB}_{\mathrm{i}} \quad=$ batas atas produksi untuk family $\mathrm{i}$

Batas bawah (LB) dapat dihitung menggunakan rumus sebagai berikut:

$L B_{i}=\sum_{\forall j \in i} \operatorname{Max}\left[0, K_{i j}\left(D_{i j, t}-I_{i j, t-1}+S S_{i j}\right)\right]$

Sedangkan untuk batas atas (UB) dihitung dengan menggunakan rumus sebagai berikut:

$\left.U B_{i}=\sum_{\forall j \in i} K_{i j}\left[\left(\sum_{k=0}^{n-1} D_{i j, t+k}\right)-I_{i j, t-1}+S S_{i j}\right)\right]$

Selanjutnya adalah penyelesaian formulasi disagregasi dengan algoritma yang dikembangkan oleh B itran dan Hax. Berikut langkah-langkahnya:

Langkah 0 atur nilai $\beta=1, P^{1}=\mathrm{x}^{*}$, dan $\mathrm{z}^{1}=\mathrm{z}$, untuk iterasi 1

Langkah 1 hitung untuk semua i $\varepsilon \mathrm{z}^{1}$ :

$y_{i}^{\beta}=\frac{\sqrt{S_{i} \sum_{y j \in i}\left(K_{i j} D_{i j, t}\right)}}{\sum_{i \in Z^{1}} \sqrt{S_{i} \Sigma_{\forall j \in i}\left(K_{i j} D_{i j, t}\right)}}$

Langkah 2 untuk semua i $\varepsilon \mathrm{z}^{1}$

if $L B_{i} \leq y_{i}^{\beta} \leq U B_{i}$, set $y_{i}^{*}=y_{i}^{\beta}$

Langkah 3 bagi family yang lain menjadi dua grup:

$Z_{+}^{\beta}=\left\{i \in Z^{\beta}: y_{i}^{\beta}>U B_{i}\right\}$ kelompok keluarga dimana $y_{i}^{\beta}>U B_{i}$

$Z_{-}^{\beta}=\left\{i \in Z^{\beta}: y_{i}^{\beta}<L B_{i}\right\}$ kelompok keluarga dimana $y_{i}^{\beta}<L B_{i}$

Hitung:

$\Delta^{+}=\sum_{i \in z_{+}^{\beta}}\left(y_{i}^{\beta}-U B_{i}\right)$

$\Delta^{-}=\sum_{i \in z_{-}^{\beta}}\left(L B_{i}-y_{i}^{\beta}\right)$

Lanjut ke langkah 4

Langkah 4

jika $\Delta^{+} \geq \Delta^{-}$maka $y_{i}^{*}=U B_{i}$ untuk semua $i \in Z_{+}^{\beta}$

jika $\Delta^{+}<\Delta^{-}$maka $y_{i}^{*}=L B_{i}$ untuk semua $i \in Z_{-}^{\beta}$

ubah $\beta=\beta+1$,

$Z^{\beta+1}=Z^{\beta}-\left(\right.$ semua keluarga dimana $y^{i}$ telah ditentukan $)$

$P^{\beta+1}=P^{\beta}-y_{i}^{*}$ (untuk semua $i$ yang dijadwalkan pada iterasi $\left.\beta\right)$

lika $Z^{\beta+1}=\emptyset$ berhenti, jika sebaliknya kembali ke langkah 1

2. $\quad$ Product Disaggregation (Disagregasi Produk)

Langkah selanjutnya adalah membagi rencana produksi tiap family menjadi rencana produksi tiap produk. Langkah-langkahnya adalah sebagai berikut:

Langkah 1 untuk tiap family i yang diproduksi, tentukan jumlah periode $\mathrm{N}$ dimana:

$y_{i}^{*} \leq \sum_{\forall j \in i} K_{i j}\left[\sum_{n=1}^{N} D_{i j n}+S S_{i j}-I_{j t-1}\right]$

Langkah 2 hitung:

$E_{i}=\sum_{\forall j \in i} K_{i j}\left[\sum_{n=1}^{N} D_{i j n}+S S_{i j}-I_{j t-1}\right]$

Langkah 3 untuk tiap item family i, hitung kuantitas produksi:

$y_{i j}^{*}=\left[\sum_{n=1}^{N} D_{i j n}+S S_{i j}-I_{j t-1}-\frac{E_{i} D_{i j n}}{\sum_{v j \in \mathrm{i}} D_{i j n}}\right]$

$\mathrm{Jika}_{\mathrm{ij}}{ }^{*}<0$ untuk item apa saja, missal $\mathrm{j}=\mathrm{g}$, maka ubah nilai $\mathrm{y}_{\mathrm{ig}}{ }^{*}=0$, hilangkan item $\mathrm{g}$ dari family, kurangi denominator paling kiri dengan $\mathrm{K}_{\mathrm{ig}} \mathrm{D}_{\mathrm{igN}}$, lalu ulangi langkah ketiga. 


\section{Pembahasan}

Proses perencanaan produksi pada PT. Singa Mas Anugerah Berkah (SMAB) karena pada ssat ini pihak manajemen tidak memiliki sistem baku dalam perencanaan produksi minyak biji kapuk. Adapun langkah awal yang dilakukanuntuk mendapatkan hasil perencanaan produksi yang baik adalah me lihat data produksi tahun 2014 dan 2015. Data tersebut menjadi acuan untuk melakukan perencanaan produksi minyak biji kapuk pada tahun 2016.

\subsection{Agregasi Data Penjualan}

Data produksi tahun 2014 dan 2015 digunakan untuk melakukan perhitungan. Agregasi data penjualan dijadikan satuan agregat. Satuan yang digunakan adalah berat produk dalam satuan ton. Berikut hasil dari agregasi data penjualan tahun 2014 sampai tahun 2015:

Tabel 1. Agregasi Data Penjualan (dalam ton)

\begin{tabular}{|c|c|c|c|c|c|c|}
\hline & Periode & Minyak & Lokal & Small Bag & Jumbo Bag & Total \\
\hline \multirow{12}{*}{2014} & Januari & 231,49 & 204,55 & 611,45 & 122 & $1.169,49$ \\
\hline & Februari & 143,769 & 299,49 & 706,08 & 84,5 & $1.233,839$ \\
\hline & Maret & 171,954 & 353,29 & 661,59 & 152,2 & $1.339,034$ \\
\hline & April & 119,34 & 111,78 & 791,24 & 48 & $1.070,36$ \\
\hline & Mei & 212,13 & 444,16 & 475,89 & - & $1.132,18$ \\
\hline & Juni & 203,67 & 398,72 & 374,5 & - & 976,89 \\
\hline & Juli & 103,85 & 294,18 & 373,32 & - & 771,35 \\
\hline & Agustus & 119,869 & 178,9 & 490,13 & 80,24 & 869,139 \\
\hline & September & 209,66 & 450,25 & 274,18 & 100,3 & $1.034,39$ \\
\hline & Oktober & 243,04 & 707,44 & 175,16 & - & $1.125,64$ \\
\hline & November & 243,51 & 343,25 & 412,59 & 300,9 & $1.300,25$ \\
\hline & Desember & 232,872 & 462,4 & 539,41 & - & $1.234,682$ \\
\hline \multirow{12}{*}{2015} & Januari & 159,23 & 203,78 & 592,13 & 100,38 & $1.055,52$ \\
\hline & Februari & 236,575 & 119,03 & 277,36 & - & 632,965 \\
\hline & Maret & 145,32 & 356,36 & 417,29 & 100,26 & $1.019,23$ \\
\hline & April & 174,6 & 429,43 & 564,84 & - & $1.168,87$ \\
\hline & Mei & 107,91 & 515,35 & 40,21 & - & 663,47 \\
\hline & Juni & 235,58 & 483,32 & 188,79 & 100,27 & $1.007,96$ \\
\hline & Juli & 50,07 & 62 & 203,58 & 100,28 & 415,93 \\
\hline & Agustus & 162,67 & 394,6 & 180,7 & - & 737,97 \\
\hline & September & 256,63 & 491,46 & 472,8 & - & $1.220,89$ \\
\hline & Oktober & 153,195 & 255,16 & 472,55 & 220,54 & $1.101,445$ \\
\hline & November & 174,87 & 268,78 & 294,72 & 160 & 898,37 \\
\hline & Desember & 78 & 457,82 & 350,99 & 220,5 & $1.107,31$ \\
\hline
\end{tabular}

Data dari tabel 1 menunjukkan hasil agregat dari produk yang dihasilkan oleh PT. SMAB. Data agregasi ini kemudian digunakan untuk melakukan peramalan permintaan dan dasar untuk menentukan penjadwalan produksi.

\subsection{Pe ramalan Permintaan}

Setelah mendapatkan agregasi data permintaan, langkah selanjutnya adalah melakukan peramalan permintaan. Sebelum mlakukan peramalan permintaan, perlu dilakukan perbandingan mean absolute deviation (MAD) dari metode yang akan digunakan untuk mengetahui manakah metode yang terbaik untuk digunakan. Metode yang akan diuji adalah moving average interval 3 bulan (MA 3), estimated weight moving average (EWMA), dan regresi linear. Berikut hasil perhitungan MAD untuk masing-masing metode: 
PERENCANAAN PRODUKS I MINYAK B IJ I KAPUK (Christian A.W., dkk.)

Tabel 2. Perbandingan MAD

\begin{tabular}{|l|c|c|c|}
\hline \multicolumn{1}{|c|}{ Famili Produk } & MA(3) & EWMA & Regresi \\
\hline Minyak & 59,8296 & 52,15277 & 47,19061 \\
\hline Bungkil Lokal & 161,2727 & 135,2774 & 118,9755 \\
\hline Bungkil Small Bag & 165,5549 & 155,4085 & 133,5844 \\
\hline Bungkil Jumbo Bag & 84,43937 & 72,8531 & 67,11235 \\
\hline
\end{tabular}

Berdasarkan hasil tersebut, metode regresi dapat digunakan untuk melakukan peramalan periode Juni tahun 2016 sampai Mei tahun 2017. Nilai yang digunakan untuk perhitungan regresi adalah sebagai berikut:

Tabel 3. Nilai a dan b Perhitungan Regresi

\begin{tabular}{|l|l|l|}
\hline \multicolumn{1}{|c|}{ Produk } & \multicolumn{1}{c|}{ a } & \multicolumn{1}{c|}{ b } \\
\hline Minyak & 182,4034 & $-0,85941$ \\
\hline Bungkil Lokal & 328,5475 & 1,753706 \\
\hline Bungkil Small Bag & 590,2344 & $-14,1984$ \\
\hline Bungkil Jumbo Bag & 38,0114 & 2,9903 \\
\hline
\end{tabular}

Dengan menggunakan nilai a dan b dari tabe 13 untuk masing-masing produk, dilakukan peramalan untuk setiap produk untuk periode Juni 2016 sampai Mei 2017. Berikut hasil peramalan untuk masing-masing produk:

Tabel 4. Peramalan Permintaan Juni 2016 sampai Mei 2017 (dalam ton)

\begin{tabular}{|c|c|c|c|c|c|c|}
\hline \multirow[b]{2}{*}{ No } & \multirow[b]{2}{*}{ Periode } & \multirow[b]{2}{*}{ Tahun } & \multicolumn{4}{|c|}{ Permintaan } \\
\hline & & & Minyak & $\begin{array}{l}\text { Bungkil } \\
\text { Lokal }\end{array}$ & $\begin{array}{c}\text { Bungkil } \\
\text { Small Bag }\end{array}$ & $\begin{array}{c}\text { Bungkil } \\
\text { Jumbo Bag }\end{array}$ \\
\hline 1 & Juni & 2016 & 156,621 & 381,159 & 164,282 & 127,720 \\
\hline 2 & Juli & 2016 & 155,762 & 382,912 & 150,084 & 130,711 \\
\hline 3 & Agustus & 2016 & 154,902 & 384,666 & 135,886 & 133,701 \\
\hline 4 & September & 2016 & 154,043 & 386,420 & 121,687 & 136,691 \\
\hline 5 & Oktober & 2016 & 153,183 & 388,174 & 107,489 & 139,682 \\
\hline 6 & November & 2016 & 152,324 & 389,927 & 93,290 & 142,672 \\
\hline 7 & Desember & 2016 & 151,465 & 391,681 & 79,092 & 145,662 \\
\hline 8 & Januari & 2017 & 150,605 & 393,435 & 64,894 & 148,653 \\
\hline 9 & Februari & 2017 & 149,746 & 395,188 & 50,695 & 151,643 \\
\hline 10 & Maret & 2017 & 148,886 & 396,942 & 36,497 & 154,633 \\
\hline 11 & April & 2017 & 148,027 & 398,696 & 22,298 & 157,623 \\
\hline 12 & Mei & 2017 & 147,168 & 400,449 & 8,100 & 160,614 \\
\hline \multicolumn{3}{|l|}{ Total } & 1822,732 & 4689,649 & 1034,294 & 1730,005 \\
\hline \multicolumn{3}{|c|}{ Rata-Rata } & 151,894 & 390,804 & 86,191 & 144,167 \\
\hline \multicolumn{3}{|c|}{ Standar Deviasi } & 3,099 & 6,323 & 51,193 & 10,782 \\
\hline
\end{tabular}

Dari perhitungan didapatkan hasil peramalan masing-masing produk untuk satu tahun ke depan. Dapat dilihat di tabel 4 bahwa hasil peramalan bahwa produk bungkil lokal dan bungkil jumbo bag mengalami peningkatan jumlah permintaan. Sedangkan untuk minyak dan bungkil small bag mengalami penurunan permintaan. Hasil ini kemudian digunakan untuk melakukan perencanaan agregat. 


\subsection{Perencanaan Agregat}

Setelah mendapatkan hasil peramalan permintaan untuk tahun 2016, tahap selanjutnya adalah melakukan perencanaan agregat. Agregasi permintaan dari produk yang ada dilakukan sebagai langkah awal melakukan perencanaan agregat. Berikut merupakan hasil agregasi peramalan untuk tahun 2016:

Tabel 5. Agregasi Peramalan Permintaan pada tahun 2016 (dalam ton)

\begin{tabular}{|c|c|c|c|c|c|c|c|}
\hline \multirow[b]{2}{*}{ No } & \multirow[b]{2}{*}{ Periode } & \multirow[b]{2}{*}{ Tahun } & \multicolumn{4}{|c|}{ Permintaan } & \multirow[b]{2}{*}{ Total } \\
\hline & & & Minyak & $\begin{array}{c}\text { Bungkil } \\
\text { Lokal }\end{array}$ & $\begin{array}{c}\text { Bungkil } \\
\text { Small Bag }\end{array}$ & $\begin{array}{c}\text { Bungkil } \\
\text { Jumbo Bag }\end{array}$ & \\
\hline 1 & Juni & 2016 & 156,621 & 381,159 & 164,282 & 127,720 & 829,783 \\
\hline 2 & Juli & 2016 & 155,762 & 382,912 & 150,084 & 130,711 & 819,469 \\
\hline 3 & Agustus & 2016 & 154,902 & 384,666 & 135,886 & 133,701 & 809,155 \\
\hline 4 & September & 2016 & 154,043 & 386,420 & 121,687 & 136,691 & 798,841 \\
\hline 5 & Oktober & 2016 & 153,183 & 388,174 & 107,489 & 139,682 & 788,527 \\
\hline 6 & November & 2016 & 152,324 & 389,927 & 93,290 & 142,672 & 778,214 \\
\hline 7 & Desember & 2016 & 151,465 & 391,681 & 79,092 & 145,662 & 767,900 \\
\hline 8 & Januari & 2017 & 150,605 & 393,435 & 64,894 & 148,653 & 757,586 \\
\hline 9 & Februari & 2017 & 149,746 & 395,188 & 50,695 & 151,643 & 747,272 \\
\hline 10 & Maret & 2017 & 148,886 & 396,942 & 36,497 & 154,633 & 736,958 \\
\hline 11 & April & 2017 & 148,027 & 398,696 & 22,298 & 157,623 & 726,645 \\
\hline 12 & Mei & 2017 & 147,168 & 400,449 & 8,100 & 160,614 & 716,331 \\
\hline \multicolumn{3}{|c|}{ Total } & $1.822,732$ & $4.689,649$ & $1.034,294$ & $1.730,005$ & $9.276,680$ \\
\hline
\end{tabular}

Setelah didapatkan data agregasi dari peramalan permintaan tahun 2016, dilakukan perumusan model perencanaan agregat yang disesuaikan dengan kondis i perusahaan. Perhitungan perencanaan agregat akan dilakukan dengan metode program linear untuk mencari jumlah produksi maksimal. Program yang akan digunakan untuk membantu perhitungan adalah Microsoft Excel Solver.

\subsection{Ide ntifikasi Komponen Biaya}

Berikut ini adalah beberapa biaya yang perlu diperhatikan dalam melakukan perencanaan agregat:

1. Biaya Tenaga Kerja Reguler

Setelah melakukan wawancara dengan pihak perusahaan diketahui perhitungan biaya tenaga kerja reguler adalah:

Biaya Tenaga Kerja Reguler $=\sum_{1}^{12} \frac{36.000 \frac{0,16 P t}{0,18}}{W t}$

Keterangan:

$\mathrm{Pt}=$ Jumlah produksi di periode $\mathrm{t}$

$\mathrm{Wt}=$ Tenaga kerja di periode $\mathrm{t}$

2. Biaya Tenaga Kerja Lembur

Biaya tenaga kerja lembur di perusahaan ini sama seperti perhitungan biaya tenaga kerja reguler karena menggunakan karyawan borongan.

3. Biaya Penambahan dan Pengurangan Tenaga Kerja

Dalam penambahan dan pengurangan tenaga kerja, pihak perusahaan tidak perlu mengeluarkan biaya tambahan. Hal ini dikarenakan sistem borongan yang berlaku di perusahaan. Tidak seperti karyawan kontrak maupun karyawan tetap yang harus diberikan kompensasi apabila terjadi pemutusan hubungan kerja.

4. Overheat

Biaya ini merupaka biaya lain selain material dan tenaga kerja. Biaya ini meliputi biaya listrik dan biaya perbaikan mesin. Biaya yang harus dikeluarkan perusahaan setiap bulannya untuk 
biaya listrik dan perbaikan adalah sebesar Rp. 110.000.000,00. Diketahui pula jumlah produksi pada tahun 2015 adalah sebanyak 12.230,253 ton. Dengan data tersebut, dilakukan perhitungan rata-rata biaya produksi lainnya untuk setiap ton hasil produksi yaitu sebesar Rp. 107.929,00. Oleh karena itu biaya produksi dapat dinotasikan sebagai berikut:

5. Biaya Simpan

Biaya Produksi Lainnya $=\sum_{1}^{12} 107.929 \mathrm{Pt}$

Dari hasil wawancara yang didapatkan dengan pihak perusahaan, diketahui bahwa selama ini PT. Singa Mas Anugerah Berkah tidak mengenal biaya simpan dalam perhitungan biaya produksi mereka. Namun sebenarnya, perusahaan tetap menanggung biaya simpan dari produk jadi yang menumpuk di gudang. Biaya simpan tersebut merupakan biaya yang seharusnya didapatkan perusahaan apabila produk tidak menumpuk di gudang. Hal ini disebut sebagai opportunity cost. Produk jadi yang tertumpuk di perusahaan berturut-turut adalah minyak sebanyak 622,117 ton, bungkil lokal sebanyak 1.136,02 ton, bungkil small bag sebanyak 227,61 ton, dan bungkil jumbo bag sebanyak 313,42 ton. Harga jual untuk minyak adalah sebesar Rp. 22.000,00 per kilogram dan harga jual bungkil adalah sebesar Rp. 1.900,00 per kilogram. Setelah dilakukan perhitungan, didapatkan bahwa biaya yang tertahan di perusahaan akibat menumpuknya barang adalah sebesar Rp. 16.872.965.200,00 untuk semua produk. Diasumsikan apabila biaya yang tertahan di perusahaan tersebut diinvestasikan di bank dengan bunga $1 \%$, maka total biaya simpan untuk semua produk yang tertahan adalah sebesar Rp. 168.729.652,00. Oleh karena itu, biaya simpan produk per ton dapat dinotasikan sebagai berikut:

Biaya Simpan $=\sum_{1}^{12} 73.387 I_{t}$

Keterangan:

It $=$ Jumlah persediaan di akhir periode

Nilai 73.387 didapatkan dari biaya yang tertahan selama tahun 2015 sebesar Rp. 168.729.652,00 dibagi jumlah keseluruhan produk sebanyak 2.299,165 ton.

Setelah mengetahui biaya-biaya apa saja yang berpengaruh dalam proses produksi, total ekspetasi biaya produksi di PT. Singa Mas Anugerah Berkah dapat dinotasikan sebagai berikut:

$Z=\sum_{1}^{12} \frac{36.000 \frac{0,16 P t}{0,18}}{W t}+\sum_{1}^{12} 107.929 P t+\sum_{1}^{12} 73.387 I_{t}$

\subsection{Optimasi Rencana Agregat}

Optimasi rencana agregat dilakukan dengan bantuan Microsoft Excel Solver. Berikut adalah hasil dari perhitungan Microsoft Excel Solver: 
JOURNAL OF INTEGRATED S YSTEM VOL 1. NO. 2, DES EMB ER 2018: 128-138

Tabel 6. Rencana Produksi Agregat Tahun 2016 (dalam ton)

\begin{tabular}{|c|c|c|c|c|c|c|c|c|}
\hline Periode & \#Ht & \#Lt & \#Wt & \#Ot & \#Pt & \#It & Demand & Kapasitas \\
\hline 0 & 0 & 0 & 20 & 0 & 0 & $2.299,165$ & - & $1.019,18$ \\
\hline 1 & 0 & 3 & 17 & 0 & 830 & $2.299,38$ & 829,783 & 866,303 \\
\hline 2 & 0 & 0 & 17 & 0 & 820 & $2.299,91$ & 819,469 & 866,303 \\
\hline 3 & 0 & 1 & 16 & 0 & 810 & $2.300,76$ & 809,155 & 815,344 \\
\hline 4 & 0 & 0 & 16 & 0 & 799 & $2.300,92$ & 798,841 & 815,344 \\
\hline 5 & 0 & 0 & 16 & 0 & 789 & $2.301,39$ & 788,527 & 815,344 \\
\hline 6 & 0 & 0 & 16 & 0 & 779 & $2.302,18$ & 778,214 & 815,344 \\
\hline 7 & 0 & 0 & 16 & 0 & 768 & $2.302,28$ & 767,900 & 815,344 \\
\hline 8 & 0 & 1 & 15 & 0 & 758 & $2.302,69$ & 757,586 & 764,385 \\
\hline 9 & 0 & 0 & 15 & 0 & 748 & $2.303,42$ & 747,272 & 764,385 \\
\hline 10 & 0 & 0 & 15 & 0 & 737 & $2.303,46$ & 736,958 & 764,385 \\
\hline 11 & 0 & 0 & 15 & 0 & 727 & $2.303,82$ & 726,645 & 764,385 \\
\hline 12 & 0 & 0 & 15 & 0 & 717 & $2.304,49$ & 716,331 & 764,385 \\
\hline Total & 0 & 5 & 189 & 0 & 9.282 & $27.624,6867$ & $9.276,68$ & $9.631,251$ \\
\hline
\end{tabular}

\subsection{Disagregasi Rencana Agregat}

Input yang digunakan untuk me lakukan disagregasi rencana agregat adalah sebagai berikut:

1. Rencana Produksi Agregat dan Peramalan Permintaan

Data ini merupakan data terpenting untuk me lakukan disagregasi rencana agregat. Data untuk rencana produksi agregat dan peramalan permintaan dapat dilihat di Tabel 5.

2. Data Persediaan Awal

Berikut merupakan data persediaan awal yang diketahui:

Tabel 7. Data Persediaan Awal

\begin{tabular}{|l|l|}
\hline \multicolumn{1}{|c|}{ Famili } & Kuantitas (Ton) \\
\hline Minyak & 622,117 \\
\hline Bungkil Lokal & $1.136,018$ \\
\hline Bungkil Small Bag & 227,610 \\
\hline Bungkil Jumbo Bag & 313,420 \\
\hline
\end{tabular}

3. Biaya Setup

Biaya setup yang diketahui dari perusahaan adalah sebagai berikut:

$$
S_{A}=S_{B}=S_{C}=\frac{110000000}{24 \times 8} \times 0,5=R p \cdot 286.458,33
$$

Setelah mendapatkan input untuk melakukan disagregasi rencana agregat, perhitungan dilakukan dengan menggunakan rumus (8) sampai dengan rumus (20). Berikut hasil dari perhitungan disagregasi rencana agregat: 
PERENCANAAN PRODUKS I MINYAK B IJ I KAPUK (Christian A.W., dkk.)

Tabel 8. Disagregasi Rencana Agregat Juni 2016 sampai Mei 2017 (dalam ton)

\begin{tabular}{|l|l|l|l|l|l|l|l|l|l|}
\hline \multirow{2}{*}{ Periode } & \multirow{2}{*}{$\begin{array}{c}\text { \#Pt } \\
\text { (Production) }\end{array}$} & Minyak & $\begin{array}{c}\text { Bungkil } \\
\text { Lokal }\end{array}$ & $\begin{array}{c}\text { Bungkil } \\
\text { Small } \\
\text { Bag }\end{array}$ & $\begin{array}{c}\text { Bungkil } \\
\text { Jumbo } \\
\text { Bag }\end{array}$ & Minyak & $\begin{array}{c}\text { Bungkil } \\
\text { Lokal }\end{array}$ & $\begin{array}{c}\text { Bungkil } \\
\text { Small } \\
\text { Bag }\end{array}$ & $\begin{array}{c}\text { Bungkil } \\
\text { Jumbo } \\
\text { Bag }\end{array}$ \\
\hline Juni & 830 & 156,662 & 381,259 & 164,325 & 127,754 & 623,383 & $1.139,100$ & 228,938 & 314,453 \\
\hline Juli & 820 & 155,863 & 383,161 & 150,181 & 130,795 & 623,484 & $1.139,348$ & 229,035 & 314,538 \\
\hline Agustus & 810 & 155,064 & 385,068 & 136,028 & 133,841 & 623,646 & $1.139,750$ & 229,177 & 314,677 \\
\hline September & 799 & 154,073 & 386,497 & 121,711 & 136,718 & 623,677 & $1.139,827$ & 229,201 & 314,704 \\
\hline Oktober & 789 & 153,275 & 388,406 & 107,553 & 139,765 & 623,768 & $1.140,059$ & 229,265 & 314,788 \\
\hline November & 779 & 152,478 & 390,321 & 93,385 & 142,816 & 623,922 & $1.140,453$ & 229,360 & 314,932 \\
\hline Desember & 768 & 151,484 & 391,732 & 79,102 & 145,681 & 623,942 & $1.140,504$ & 229,370 & 314,951 \\
\hline Januari & 758 & 150,688 & 393,650 & 64,929 & 148,734 & 624,024 & $1.140,719$ & 229,405 & 315,032 \\
\hline Februari & 748 & 149,892 & 395,573 & 50,745 & 151,791 & 624,170 & $1.141,104$ & 229,455 & 315,180 \\
\hline Maret & 737 & 148,895 & 396,964 & 36,499 & 154,642 & 624,179 & $1.141,127$ & 229,457 & 315,189 \\
\hline April & 727 & 148,099 & 398,891 & 22,309 & 157,701 & 624,251 & $1.141,322$ & 229,468 & 315,266 \\
\hline Mei & 717 & 147,305 & 400,824 & 8,108 & 160,764 & 624,389 & $1.141,696$ & 229,475 & 315,416 \\
\hline
\end{tabular}

Dari tabel 8 dapat dilihat hasil produksi untuk tiap bulan dari Juni 2016 sampai Mei 2017. Hasil produksi tersebut kemudian dibagi sesuai disagregasi agregat tiap produk. Hasil disagregasi ini kemudian digunakan sebagai acuan membuat perencanaan produksi.

\subsection{Master Production Schedule}

Setelah mendapatkan hasil disagregasi rencana agregat, dapat dibuat Master Production Schedule sebagai rencana produksi periode Juni 2016 sampai Mei 2017. Berikut merupakan MPS untuk periode Juni 2016 sampai Mei 2017:

Tabel 9. Master Production Schedule (dalam ton)

\begin{tabular}{|l|c|c|l|l|}
\hline \multirow{3}{*}{ Periode } & \multicolumn{4}{|c|}{ Master Production Schedule } \\
\cline { 2 - 5 } & Minyak & $\begin{array}{c}\text { Bungkil } \\
\text { Lokal }\end{array}$ & $\begin{array}{c}\text { Bungkil } \\
\text { Small Bag }\end{array}$ & $\begin{array}{c}\text { Bungkil } \\
\text { Jumbo Bag }\end{array}$ \\
\hline Juni & 156,662 & 381,259 & 164,325 & 127,754 \\
\hline Juli & 155,863 & 383,161 & 150,181 & 130,795 \\
\hline Agustus & 155,064 & 385,068 & 136,028 & 133,841 \\
\hline September & 154,073 & 386,497 & 121,711 & 136,718 \\
\hline Oktober & 153,275 & 388,406 & 107,553 & 139,765 \\
\hline November & 152,478 & 390,321 & 93,385 & 142,816 \\
\hline Desember & 151,484 & 391,732 & 79,102 & 145,681 \\
\hline Januari & 150,688 & 393,650 & 64,929 & 148,734 \\
\hline Februari & 149,892 & 395,573 & 50,745 & 151,791 \\
\hline Maret & 148,895 & 396,964 & 36,499 & 154,642 \\
\hline April & 148,099 & 398,891 & 22,309 & 157,701 \\
\hline Mei & 147,305 & 400,824 & 8,108 & 160,764 \\
\hline
\end{tabular}

Tabel 9 merupakan MPS yang juga merupakan perencanaan produksi minyak dan bungkil PT. SMAB selama period Juni 2016 sampai Mei 2017.Perencanaan ini sudah mempertimbangkan berbagai aspek yang mempengaruhi proses produksi mulai dari permintaan, kapasitas produksi, 
biaya dan faktor penunjang lainnya. Karena itu, perusahaan dapat menggunakan perencanaan ini sebagai pertimbangan me lakukan proses produksi.

\section{Kesimpulan dan Saran}

Dari perhitungan yang telah dilakukan, didapatkan MPS yang dapat menjadi acuan perusahaan untuk melakukan proses produksi. Berdasarkan MPS tersebut, perusahaan dapat mengetahui berapa jumlah bahan baku yang harus disediakan untuk memenuhi permintaan yang ada. Saran yang diberikan untuk penelitian serupa adalah sebaiknya metode yang digunakan mengikuti perkembangan yang ada sehingga hasil yang didapatkan lebih maks imal.

\section{Daftar Pus taka}

Bitran, G.R., Haas, E.A. dan Hax, A.C., (1982), "Hierarchial Production Planning, A Two Stage System", Journal of Operations Research, Vol. 30, pp. 232-251.

Herjanto, E., (2007), Manajemen Operasi Edisi Ketiga, PT. Gramedia Widiasarana Indonesia, Jakarta.

Sukendar, I. dan Kristomi, R., (2008) "Metoda Agregat Planning Heuristik Sebagai Perencanaan dan Pengendalian Jumlah Produksi untuk Minimasi Biaya", http://journal.uii.ac.id/index.php/Teknoin/article/viewFile/2102/1910, Diakses pada hari Kamis, 3 Desember 2015 Pk. 10.00 WIB. 